\title{
3B Kent Modelleri İçin Yeni Bir Silüet Analizi Modülünün Geliştirilmesi
}

\author{
Sebahat TEMUÇIN KILIÇER ${ }^{1 *}$, Çetin CÖMERT ${ }^{2}$, Halil AKINCI ${ }^{3}$ \\ ${ }^{1}$ Artvin Çoruh Üniversitesi, Mühendislik Fakültesi, Harita Mühendisliği Bölümü, Artvin \\ (stemucin@artvin.edu.tr) ORCID ID 0000-0001-5839-6616 \\ ${ }^{2}$ Karadeniz Teknik Üniversitesi, Mühendislik Fakültesi, Harita Mühendisliği Bölümü, Trabzon \\ (ccomert@ktu.edu.tr) ORCID ID 0000 - 00002 - 2019 - 6990 \\ ${ }^{3}$ Artvin Çoruh Üniversitesi, Mühendislik Fakültesi, Harita Mühendisliği Bölümü, Artvin \\ (hakinci@artvin.edu.tr) ORCID ID 0000 - 0002 - 9957 - 1692
}

\section{Öz}

Üç boyutlu kent modelleri; arazi yüzeyleri, yerleşim bölgeleri, binalar, bitki örtüsü, altyapı ve peyzaj öğeleri gibi kentsel alanlara ait nesneleri içeren dijital temsilleridir. Üç boyutlu kent modelleri, bilgisayar oyunları ve eğitim amaçlı kullanıldı̆̆ gibi kentsel planlama, afet yönetimi, tesis yönetimi, lojistik, güvenlik, telekomünikasyon, konumsal servisler, gayrimenkul değerlendirmeleri gibi birçok farklı uygulamada sunum, üretim, analiz ve yönetim görevlerinde de kullanılmaktadır. 3B konumsal analizlerden biri olan silüet analizi, kentsel alan düzenlemesi ve peyzaj planlaması için önemli analizlerdendir. Silüet analizleri, özellikle kentsel alanlarda kent simgesi haline gelmiş önemli binaların silüetinin korunması için kullanılmaktadır. Yaygın kullanılan Coğrafi Bilgi Sistemleri yazılımlarından biri olan ArcGIS, sahip olduğu 3D Analyst modülünün sunduğu fonksiyonlar sayesinde çeşitli görünürlük analizlerinin gerçekleştirilmesine olanak sağlamaktadır. Ancak, 3D Analyst modülünde binaların silüet görünümünü oluşturacak bir fonksiyon bulunmamaktadır. Bu çalışmada, ArcGIS yazılımı için Python programlama dili kullanılarak bir silüet analiz modülü geliştirilmiş ve bu modülün kullanılacağı bir araç çubuğu tasarlanmıştır. Silüet analiz modülü, gözlem yapılan noktadan belirli bir görüş alanında kalan binaların silüet görüntüsünü üretebilmekte ve aynı alanda yapılması düşünülen yeni binaların silüete etkilerini tespit edebilmektedir. Ayrıca siluet analiz modülünün kullanılması ile yeni yapılan binanın kent silüetini bozup bozmadığı belirlenebilmekte ve yeni binaların maksimum yüksekliği ve kat adedi hesaplanabilmektedir. Böylelikle kentsel planlama sürecinde ve imar planlarının uygulanmasında karşılaşılan kentsel silüetin bozulması problemlerinin çözümüne önemli katkı sağlanmıştır.

Anahtar Kelimeler: CBS, 3B kent modelleri, kentsel planlama, silüet analizi, ArcGIS, Python

\section{Development of a New Silhouette Analysis Module For 3D City Models}

\begin{abstract}
3D city models are digital representations of objects such as terrain surfaces, sites, buildings, vegetation, infrastructure and landscape elements belonging to urban areas. 3D city models are used in presentation, exploration, analysis, and management tasks for a large number of different applications including urban planning, disaster management, facility management, logistics, security, telecommunication, location-based services, real estate portals as well as being used for computer games and educational purposes. Silhouette analysis, one of 3D spatial analyses, is important for urban area designing and landscape planning. Silhouette analysis is used to protect the silhouette of important buildings that have become landmark especially in urban
\end{abstract}

* Sorumlu Yazar 
areas. As a widely used software in the Geographical Information Systems (GIS) market, ArcGIS has a module called "3D Analyst Tools" that provides opportunities for enabling various visibility analyses with the help of functions within that module. However, the 3D Analyst Tools does not have a function to create a silhouette view of buildings. In this study, a silhouette analysis module was developed using the Python programming language for the ArcGIS software and a toolbar was designed to use this module. Silhouette analysis module can produce a silhouette view of buildings in a certain field of view from the observation point and can track changes on silhouette when new buildings planned to be built in the same area. In addition, the use of the new silhouette analysis module can determine whether a newly built building has distorted the urban silhouette and calculates the maximum height and floor number of new buildings. Thus, important contribution was provided in solving the distortion problems of urban silhouette encountered in the urban planning process and in the implementation of the development plans.

Keywords: GIS, 3D city models, urban planning, silhouette analysis, ArcGIS, Python

\section{GíRiş}

Genel olarak, "konumsal veri tabanı yönetimi için tasarlanmış yazılım ve donanım elemanlarının bütünü (Masry ve Lee, 1988)" şeklinde tanımlanan Coğrafi Bilgi Sistemleri (CBS), dünya üzerindeki karmaşık sosyal, ekonomik ve çevresel sorunların çözümüne yönelik konuma dayalı karar verme süreçlerinde yaygın olarak kullanılmaktadır. CBS, konumsal verilerin gösterimi ve sunumunun ötesinde, sahip olduğu iki boyutlu (2B) ve üç boyutlu (3B) veri modelleme, sorgulama ve analiz fonksiyonları sayesinde turizm, çevre, enerji, tarım, orman, ulaşım, afet ve acil durum yönetimi, araç takibi, kentsel planlama, şehircilik ve arazi kullanım uygulamaları gibi farklı birçok alanda karar vericilerin doğru kararlar almasına katk1 sağlamaktadır.

Konumsal verilerin 2B düzlemde temsil edilmesiyle üretilen 2B haritalar, CBS'nin kullanıldığ1 birçok çalışmada altlık olarak kullanılmaktadır. Ancak, gürültü tahmin modelleri (Kluijver ve Stoter, 2003), hava kirliliği modelleri, taşkın modelleri, jeolojik modeller (Van Wees vd., 2002) ve emlak piyasas1 (Stoter ve Zlatanova, 2003; Stoter ve Ploeger, 2003) ile ilgili uygulamalarda 2B konumsal verilerin ve bu veriler üzerinde gerçekleştirilen analizlerin yetersiz kaldığ1 görülmektedir (Stoter ve Zlatanova, 2003). Donanım ve bilgisayar grafiklerindeki gelişmeye paralel olarak uygulamalarda 3B veriye olan talebin artmasi, konumsal veri modellemesinde üçüncü boyuta odaklanılmasını sağlamıştır (Zlatanova vd, 1998). Böylelikle yeryüzünde bulunan enerji nakil hatları, aydınlatma direkleri, yollar, ağaçlar ve binalar gibi objeler bilgisayar ortaminda 3B temsil edilerek "3B Kent Modelleri" üretilmiștir. 3B kent modellerinin kullanıldığ1 uygulama alanlarının genişlemesi ile birlikte 3B konumsal modelleme ve analizler, günümüzde CBS alanında önemli araştırma konuları haline gelmiştir.

Literatürde 3B kent modelleri kullanılarak kentsel alanların planlanması ve yönetimine katkıda bulunan birçok çalışma bulunmaktadır. Sadek vd. (2002) tarafından yapılan çalışmada, şehirlerin 3B görselleştirilmesi için şehir plancılarının kullanabileceği bir 3B kent modeli oluşturulmuştur. Czerwinski vd. (2007) tarafından yapılan çalışmada, Almanya'nın nüfusa göre birinci şehri olan North RhineWestphalia'da 3B modellenen binaların gürültü emisyon hesapları ile gürültü analizleri yapılmıştır. Ban vd. (2011) tarafindan yapılan ViSuCity projesi ile sürdürülebilir kent ve çevre planlamasını desteklemek için web tabanlı interaktif bir görüntüleyici tasarlanmıştır. Lamberti vd. (2011), 3B kent modelini kullanarak cadde ve sokakların aydınlatılması üzerine çalışmışlardır (Mao, 2011). Schulte ve Coors (2008), 3B tasarlanmış binaların taşkın simülasyonunu yaparak afet yönetimi alanında uygulama geliştirmişlerdir. Lee ve Zlatanova (2008) ise yangın gibi insanların acil tahliye edilmesi gereken durumlarda uygun tahliye yollarını belirlemek için binaların 3B modellenmesi ve 3B topolojik analizler üzerinde çalışmışlardır.

Gürültü analizi (noise analysis), hava kirliliği analizi (air pollution analysis), ağ analizi (network analysis), gölge analizi (shadow analysis), görünürlük analizi (visibility analysis) ve silüet analizi (silhouette analysis) gibi konumsal analizler, 3B CBS uygulamalarında ihtiyaç duyulan analizlere örnek olarak gösterilebilirler. Görünürlük 
analizleri, 1970'li y1llardan beri CBS uygulamalarında kullanılan analizlerdir (Yang vd., 2007). Görünürlük analizleri; özellikle kentsel planlama, çevre düzenlenmesi, peyzaj planlamaları ile baz istasyonları, rüzgâr türbinleri ve güneş enerjisi sistemlerinin kurulacağı alanların belirlenmesi gibi uygulamalarda yaygın olarak kullanılmaktadır.

Görünürlük analizleri içinde yer alan silüet analizi, kentsel planlamada kent mimarisini korumak ve imar planlarının üretilmesinde doğru kararlar verebilmek açısından büyük öneme sahiptir. Güney vd. (2012) çalışmalarında iki ayrı silüet tanımına yer vermişlerdir. Birincisinde silüet, "yerin ve gökyüzün buluştuğu çizgi, ufuk; bunun resim veya başka bir sanattaki temsili" olarak tanımlanmaktadır. İkincisinde ise silüet, "bir veya bir dizi binanın veya gökyüzünde görülen diğer nesnelerin taslağı" olarak tanımlanmaktadır. Kentsel silüet veya şehir silüeti ise kentsel alanlardaki binaların bir noktadan olan görüntüsü olarak tanımlanabilir. Literatürde, kentsel alanlardaki binaların silüetlerini üreten çeşitli çalışmalar bulunmaktadır. Örneğin, Nasar ve Terzano (2010) tarafından, dijital fotoğraflar kullanarak doğal ve kentsel alanların silüetlerini kıyaslayan bir çalışma yapılmıştır. Yusoff vd. (2014) tarafından, 3B kent modeli kullanarak Kuala Lumpur şehrinin silüetinin korunmasına yönelik çalışmalar yapılııştır. Czyńska (2015) tarafından yapılan çalışmada, kentsel alanlarda yüksek yapılı binaların tarihi yapılar üzerindeki etkisi incelenmiştir. Tafahomi vd. (2016) tarafindan yapılan çalışmada ise İran'ın ikinci büyük şehri olan Mashhad şehrindeki binalara ait silüet çalışmaları yapılmıştır. Tavernor ve Grassner (2010) ise Londra'daki yüksek yapılı kulelerin, Waterloo köprüsü ve St. Paul katedrali üzerindeki görsel etkisini incelemişlerdir. Akdag vd. (2010), İstanbul'da Zincirlikuyu-Malak yolunda yer alan yüksek katlı binaların İstanbul Boğazındaki silüetin değişimine olan etkilerini incelemişlerdir. Güney vd. (2012), kentsel alanların planlamasinda kent silüeti öneminin vurgulandığı çalışmalarında, İstanbul'un Levent semti civarında pilot bir bölge belirleyerek çalışma alanının 3B kent modelini oluşturulmuşlardır. Boğaziçi Köprüsü, Fatih Sultan Mehmet Köprüsü, Harem ve Çamlıca Tepesi gibi şehrin önemli noktalarından çalışma alanının görünürlügü incelenmiş ve çeşitli 3B analizler gerçekleştirmişlerdir. Şahin vd. (2012), mevcut durumun belgelenmesini, kent plancilarının tasarım kararlarını kolaylaştırmayı, binaların mekânla ve birbirleriyle ilişkilerini daha kolay kurgulamayı amaçladıkları çalışmalarında fotogrametrik yöntemlerle silüet görüntüsü üretmişlerdir. Çalışmada, Rolleiflex6008 metrik resim çekim kamerası kullanılarak çekilen resimlerden Pictran D yazilımıyla stereo modeller oluşturulmuştur. Ardından, stereo model üzerinden silüet çizimleri yapılmış ve AutoCAD ortamına aktarılmıştır. Yastıklı vd. (2017) tarafindan yapilan çalışmada ise yersel sayısal fotogrametrinin sunduğu imkânlar kullanılmıştır. Çalışmada, İstanbul Boğazı'nda yap1 yasağı bulunan Sarıer Yenimahalle'sinde siluetin korunmas ve değişimlerin izlenmesi amaciyla bir uygulama gerçekleştirilmiştir. Bu uygulamada, kalibre edilmiş Nikon D3X sayısal SLR kamera kullanılarak konvergent alım yöntemi ile çalışma alanının denizden sayısal fotoğrafları kaydedilmiştir. Daha sonra, PhotoModeler yazılıminda bu sayisal fotoğraflar kullanılarak yönelme işlemleri, 3B siluet çizimi ve nokta bulutu üretimi gibi işlemler gerçekleştirilmiştir.

Şehirlerin doğal ve tarihi güzellikleri, kültürü, hatta geçmiş medeniyetlere ait kültürel etkileri, bir şehrin cadde, sokak ve binalarına tarihi doku olarak yansımaktadır. Şehirlerin köprüleri, kaleleri, camileri, kuleleri, duvar ve surları gibi tarihi yapıları zamanla o şehirle özdeşleşen objeler haline gelmektedir. Benzer şekilde, söz konusu yapıların silüetleri de bulundukları şehirleri temsil eden simgelere dönüşmektedir. Kent silüetleri sadece simge olarak kullanılmamaktadır. Kent silüetleri, aynı zamanda, çevre düzeni planları, mekansal strateji planları, kentsel dönüşüm planları ve imar planları gibi kentsel alanlara yönelik planlamalarda ihtiyaç duyulan önemli bir veridir.

Kültürel değerler ile doğal güzelliklerin bulunduğu ve doğal yapının korunması gerektiği alanlarda mevcut silüetin korunmas1, şehir simgesi haline gelmiş yapıların silüetinin korunması veya turistik öneme sahip stratejik noktaların turistik önemini kaybetmemesi için silüetinin korunması gibi durumlar, silüet analizlerine olan gereksinimi ortaya koymaktadır. Bununla birlikte, hızlı nüfus 
artış1 ve kırsal kesimden kentlere olan yoğun göç nedeniyle konut talebinin artması, buna bağlı olarak hızlı yapılaşma faaliyetlerinde rant kaygısı ve yerel yönetimlerin yetersizlikleri, kentlerin doğal ve tarihi çevresine zarar vermekte ve kentlerin silüetleri bozulmaktadır.

Kuala Lumpur, Singapur, Chicago, Miami, Londra ve İstanbul gibi mega kentlerde hızla yükselen gökdelenlerin kentin silüeti üzerindeki olumsuz etkileri birçok kez gündeme getirilmiştir. İstanbul' da Dolmabahçe Sarayı ve arkasında hızla yükselen binalara ait silüet ile Haliç Metro Geçiş Köprüsü'nün Unkap1 Köprüsü ve Tarihi Yarımada'daki silüete etkileri çeşitli çalışmalarda incelenmiştir. Zincirlikuyu ve Maslak gibi hızla gelişmekte olan ve bir yatırım firsatı haline gelen bölgelerdeki binaların, İstanbul'un kentsel silüetine etkileri geçtiğimiz y1llarda sıç̧a gündeme getirilmiş hatta bazı binalar için Tarihi Yarımada' daki silüet dokusunu bozduğu için mahkeme tarafından yıkım kararı verilmiştir.

İmar planlarına uygun olarak inşa edilen ruhsatlı binalar için silüeti bozduğu gerekçesiyle yıkım kararı verilmesi bir yandan önemli ekonomik kayıplara neden olmakta diğer yandan da "bu binalar inşa edilmeden önce daha proje aşamasında iken silüeti bozup bozmadığ 1 belirlenemez miydi?" sorusunu akla getirmektedir.

Günümüzde yaygın olarak kullanılan ticari veya açık kaynak kodlu CBS yazılımları, sundukları 3B analiz fonksiyonları ile çeşitli analizlerin yapılmasına olanak sağlamalarına rağmen silüet analizi konusunda yetersiz kalmaktadırlar. Silüet analizinin yetersizliği, "hangi binaların silüeti bozduğu, hangilerinin bozmadığı, silüetin bozulmaması için nereye ne kadar yükseklikte bina yapılması gerektiği, farklı noktalardan bakıldığında silüetin nasıl değiştiği” gibi soruları yanıtsız bırakmaktadır. Kentsel alanların planlanması ve imar planı uygulamaları sürecinde, kentsel silüet analizlerine olanak sağlayan yazilımların bulunmas1, karar vericilerin benzer sorulara cevap bularak doğru karar vermelerine katk1 sağlayacaktır.

ESRI (Environmental Systems Research Institute Inc) firması tarafindan geliştirilen ArcGIS yazılımı, CBS'nin veri girişi, işleme, sorgulama, analiz ve sunum gibi temel modülleri ile ilgili birçok fonksiyon sağlamakta ve tüm Dünya'da yaygın olarak kullanılmaktadır. ArcGIS yazılımı, verileri 3B olarak temsil edebilmekte ve sunduğu "3D Analyst" modülü ile çeşitli konumsal analizlere olanak sağlamaktadır. 3D Analyst modülünün görünürlük analizleri alt modülü; görüş hatları çizme analizi (construct sight lines), görüş analizi (intervisibility), görüş hattı analizi (line of sight), gözlemci noktaları analizi (observer points), gölge analizi (sun shadow volume), görüş alanı analizi, görünürlük analizi ile skyline, skyline bariyer ve skyline grafik analizleri gibi görünürlük analizlerinde kullanılan çeşitli fonksiyonlara sahiptir. $\mathrm{Bu}$ analiz fonksiyonlarının birçoğu, genel olarak, arazi yüzeyi, 3B bina modelleri veya diğer $3 \mathrm{~B}$ objeleri dikkate alarak bir noktadan görülebilen veya görülemeyen alanların belirlenmesine olanak sağlamaktadır. Söz konusu analiz fonksiyonları kullanılarak, 3B binaların silüet görüntüsü üretilememekte veya yeni yapılacak binaların tarihi veya kültürel öneme sahip binaların silüetini bozmaması için sahip olması gereken yükseklik veya kat adedi gibi özellikleri hesaplanamamaktadır. Bu çalışmada, Python programlama dili kullanılarak ArcGIS CBS yazılımında silüet analizlerinin gerçekleştirilmesine olanak sağlayan yeni bir modülün tasarlanması ve gerçekleştirilmesi amaçlanmıştır.

\section{YÖNTEM}

$\mathrm{Bu}$ çalışmada, 3B kent modelini kullanarak silüet analizi gerçekleştirme yeteneğine sahip olan bir modülün geliştirilmesi için sırasıyla aşağıdaki işlem adımları izlenmiştir.

- Örnek bir çalışma alanına ait bina katmanının ve Sayısal Yükseklik Modeli (SYM)'nin üretilmesi,

- CityEngine programında 3B bina modellerinin üretilmesi,

-3B bina modellerinin ArcGIS ortamina aktarilmas1,

- Python programlama dili ve PyScripter programı ile silüet analizi modülünün geliştirilmesi,

- ArcGIS Python Add-In Wizard programı ile silüet analiz modülü için araç çubuğunun 
(toolbar) tasarlanması ve ArcGIS programına entegre edilmesi,

- Geliştirilen silüet analiz modülü kullanılarak örnek bir çalışma alanındaki binaların silüet görüntüsünün üretilmesi.

Yukarıda sıralanan işlemler çalışmada dört ana başlık altında ele alınmakta ve açiklanmaktadır: CityEngine programı kullanılarak örnek bir çalışma alanındaki binaların 3B bina modelinin üretilmesi, üretilen 3B modeldeki binalar için Pyhton programlama dili kullanılarak silüet analizini gerçekleștirecek olan silüet analiz modülünün geliştirilmesi, geliştirilen silüet analiz modülünün ArcGIS yazılımına entegre edilmesi için bir araç çubuğunun tasarlanması, ve son olarak, silüet analiz modülünün çalışma prensibi ve analiz çıktılarının örnek bir uygulama ile gösterilmesi.

\subsection{B Bina Modellerinin Üretimi}

ArcGIS programinda silüet analizini gerçekleştirmek için ilk olarak örnek bir çalışma alanının SYM'si üretilmiştir. Çalışmada kullanılan SYM, 1/1000 ölçekli halihazır haritalardaki eşyükseklik eğrileri kullanılarak üretilmiştir. Belediyelerden temin edilebilecek olan sayısal 1/1.000 ölçekli halihazır haritalardaki bina katmanları ve bina yükseklikleri kullanılarak 3B bina modelinin üretilmesi mümkündür. Ancak bu çalışmada, silüet analizindeki farklı durumları (örneğin binaların farklı şekil ve yüksekliklerde olması, birbirlerine göre farklı konumlarda olmas1, durulan noktaya ve görüş hattına farklı uzaklıklarda olması ve estetik bir silüet görüntüsü elde edilebilecek şekilde konumlandırılmış olmaları gibi farklı bütün faktörleri) göz önünde bulunduracak şekilde sanal bir bina katmanı oluşturulmuştur. ESRI Shape formatında üretilen bina katmanına kat adeti özniteliği eklenmiş ve tüm binaların sanal kat adetleri öznitelik tablosuna girilmiştir. Daha sonra CityEngine v.2015.2 programında kat adetleri kullanılarak çalışma alanına ait bina katmanından 3B bina modelleri üretilmiştir. CityEngine programında 3B model üretimi tamamlandiktan sonra konumsal analizlerin gerçekleştirilebilmesi için verinin dışa aktarılması gerekmektedir. Bu nedenle, üretilen 3B bina modeli ArcGIS ortaminda kullanılmak üzere multipatch veri yapısında dışa aktarılmıştır.

\subsection{Silüet Analizi Modülünün Geliştirilmesi}

ArcGIS programı, nesne yönelimli (objectoriented) bir programlama dili olan Python programlama dili kullanılarak genişletilme imkânı sunmaktadır. ArcGIS programı kullanıcılarına masaüstü CBS yazılımları ile birlikte IDLE editörünü de sunmaktadır. Fakat bu çalışmada, daha pratik olduğu düşünülen PyScripter editörü kullanılarak silüet analizi için gerekli kodlar yazılmıştır. Bu çalışma kapsamında geliştirilen silüet analizi modülü ile 3B kentsel alanlarda, kullanıcılar tarafindan belirlenecek olan bir durulan nokta ve bir görüş hattındaki belirli binalara ait silüet görüntüsü üretilebilmektedir. Ayrıca mevcut binalardan silüetinin korunması önem arz eden bina seçilerek, silüeti korunmak istenen bina ile yeni yapılacak olan bina arasında silüet analizi gerçekleştirilmektedir. $\mathrm{Bu}$ analiz ile yeni binanın, korunan bina silüetini bozmaması için maksimum bina yüksekliği ve yapilabilecek maksimum kat adedi hesaplanabilmektedir. Böylelikle kentsel alanlarda yeni bir bina yapılacağı zaman silüet analizi uygulanarak yeni yapılacak binanın silüet durumu hem görsel hem de sayısal olarak yorumlanabilmektedir. Çalışmada geliştirilen silüet analizi modülüne ait akış diyagramı ise Şekil 1'de gösterilmektedir. 


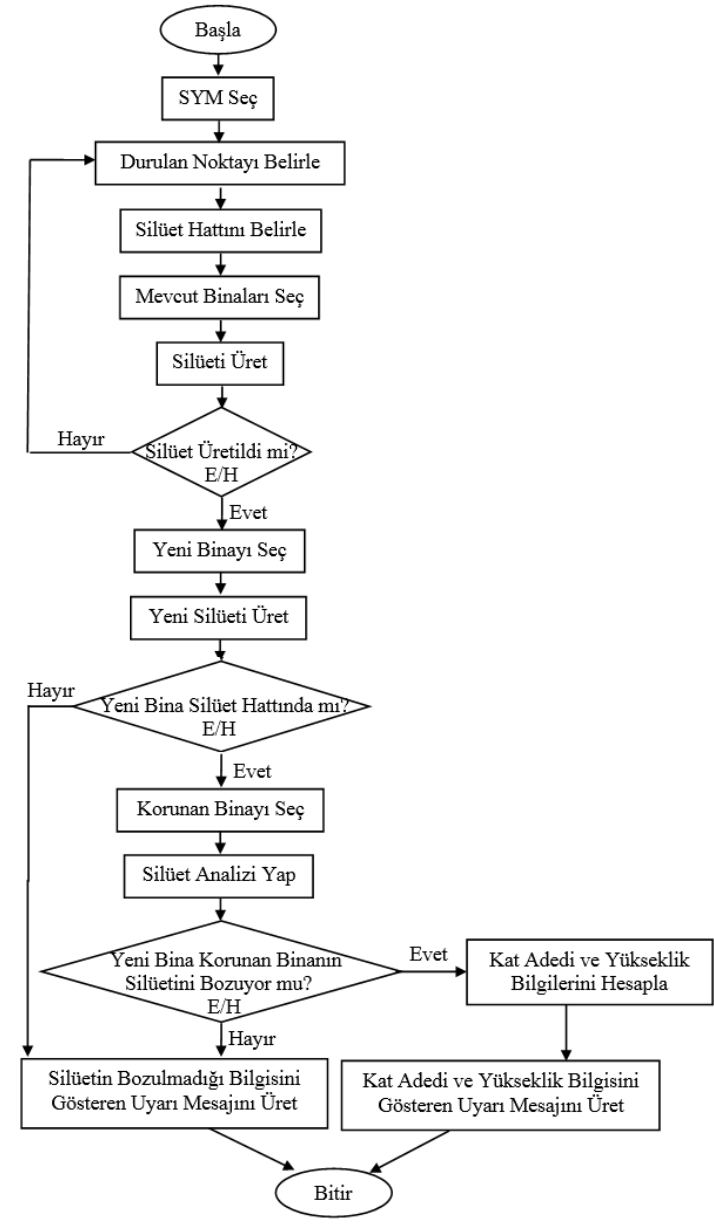

Şekil 1. Akış Diyagramı

\subsection{Silüet Analiz Modülü için Araç Çubuğunun Tasarımı}

ArcGIS Python Add-In Wizard program1 pratik olarak araç çubuğu tasarımına imkân sağlamaktadır. $\mathrm{Bu}$ çalışmada, silüet analizi modülü için Şekil 2'de gösterilen "Silhouette" isimli araç çubuğu tasarlanarak ArcMap programında kullanıma sunulmuştur. Tasarlanan silhouette araç çubuğu kullanıcıya pratiklik sağlaması ve kullanıcıyı bilgi karmaşasından kurtarmak adına aşağıda ifade edilen özellikleri kullanıcıya sunmaktadır.

- Araç çubuğunda yer alan butonlar, silüet analizindeki işlem adımlarının akışına göre aktif hale gelecek șekilde kodlanmıștır. Örneğin, Layer isimli açılır kutudan raster formatta bir yüzey modeli seçildiği anda bu açılır kutuya ait işlemler tamamlanmakta ve silüet analizi için gözlem yapılacak durulan noktanın belirlenmesine olanak sağlayan "Observation Point" isimli buton aktif hale gelmektedir.

- Araç çubuğundaki Layer isimli açılır kutu sadece raster formattaki sayısal yükseklik modelini, Building ve New Building isimli açılır kutular sadece multipatch veri yapısındaki binaları, Protected Building isimli açı1ır kutu ise silüet analizine giren multipatch veri yapısındaki binaları listeleyebilecek şekilde kodlanmıştır. Örneğin, Table of Context'de multipatch formatında birçok bina bulunurken, Protected Building sadece silüete giren multipatch binalardan bir seçim yaptırmaktadır. Ayrıca normalde açılır kutular belirtilen veri yapılarını görüntüleyebilmekte iken, burada uygulamaya yeni veriler eklediği anda açılır kutular bu veriyi de gösterebilmektedir.

- Silüet analiz modülünde analiz işlemleri bazı özel durumlarla karşılaşıldığında işlemi durdurarak dikkat edilmesi veya yapılması önem arz eden bilgi veya uyarıları mesaj kutusu olarak ekranda göstererek kullanıcının yapacağ 1 düzeltmelerle işlemi kaldığı yerden devam ettirebilmektedir.

- Analiz sonucunda üretilen silüet görüntüleri, dosya adına tarih ve saat bilgileri eklenerek kayıt edilmektedir. Ayrıca üretilen silüet görüntüleri hem ESRI shape formatında hem de ayr1 bir pencerede SVG formatında gösterebilmektedir.

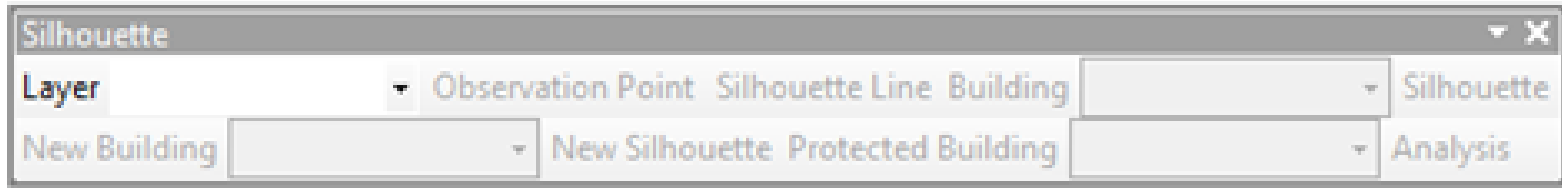

Şekil 2. Silhouette Araç Çubuğu 


\subsection{Uygulama}

$\mathrm{Bu}$ çalışmada, silüet analizi çalışmaları yapılacak bölgeye ait 3B bina modellerini üretebilmek adına SYM ve CityGML standartlarına göre LoD 1 seviyesinde blok modeller olarak farklı yapılarda 17 ayrı bina modeli üretilmiştir. CityEngine programı 2015.2 versiyonu kullanılarak oluşturulan 3B bina modellerinin ArcGIS 10.2 programındaki görünümü Şekil 3'de gösterilmektedir. Üretilen $3 \mathrm{~B}$ bina modellerinden silüet analizinde yeni bina olarak bahsi geçen ve silüet durumu değerlendirilecek olan bina kırmızı renkte gösterilmektedir.

$\mathrm{Bu}$ uygulama ile bir durulan nokta ve silüet hatt1 belirlenerek hem sadece mevcut binalarin silüet görüntüsü hem de yeni yapılacak binanın mevcut binalarla olan silüet görüntüsü üretilmektedir. Ayrıca mevcut binalardan silüetinin korunması önem arz eden bina kullanıcıya seçtirilmekte ve silüeti korunmak istenen bina ile yeni yapilacak olan bina arasında bir silüet analizi gerçekleştirmektedir. $\mathrm{Bu}$ analiz ile yeni binanın silüeti korunmas istenilen binanın silüetinin bozup bozmadığ 1 değerlendirilmektedir.

Yeni binanın korunan bina silüetini bozmaması durumunda, yeni binanın korunan binanın silüetini bozmadığına dair bir bilgi mesaj1 sunulmaktadır. Yeni binanın korunan binanın silüetini bozmas1 durumunda ise yeni bina ve korunan bina arasinda analiz gerçekleştirilmektedir. Böylelikle yeni binanın korunan bina silüetini bozmaması için sahip olması gereken maksimum bina yüksekliği ve yapilabilecek maksimum kat adeti hesaplatılarak bu değerler başka bir bilgi mesajı ile sunulmaktadır. Silüet analiz modülünün işlem adımları aşağıda sırasıyla açıklanmıştır.

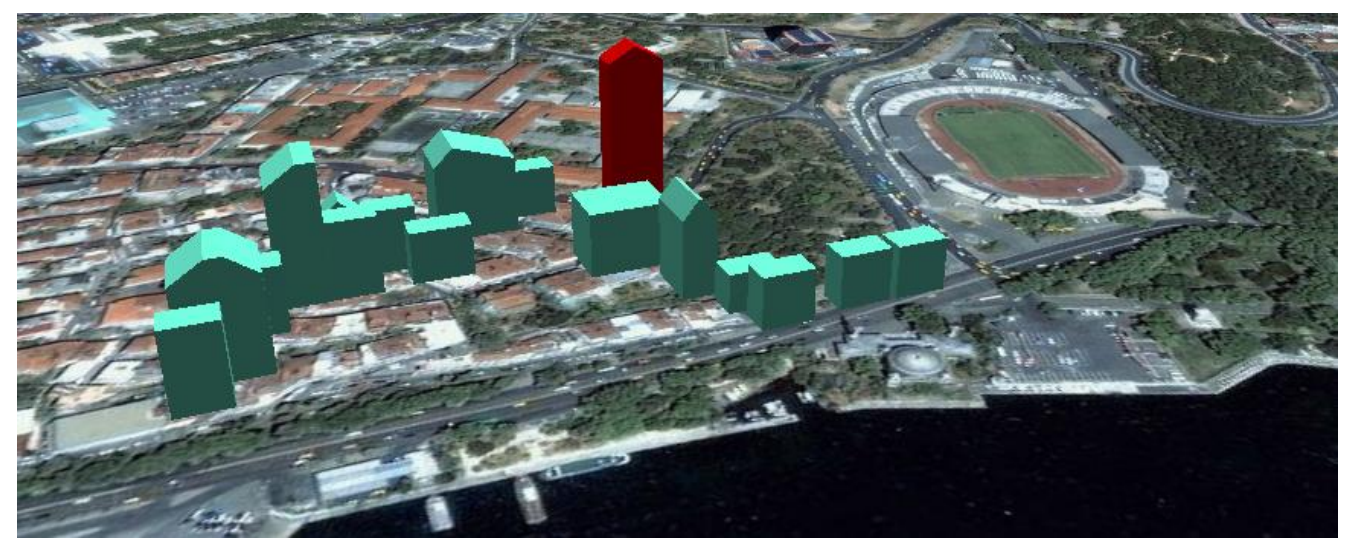

Şekil 3. 3B Bina Modellerinin ArcGIS 10.2 Yazılımında Gösterimi

1. Kullanıcı araç çubuğundaki Layer isimli açı1ır kutuyu kullanarak çalışma alanına ait SYM'yi harita penceresine yükler (Şekil 4).

2. Kullanıcı daha sonra araç çubuğundaki Observation Point butonunu kullanarak silüet görüntüsünün üretileceği durulan noktayı SYM üzerinde işaretler (Şekil 4).

3. Kullanıcı araç çubuğundaki Silhouette Line butonunu kullanarak silüet hattını belirler. Silüet hattı, kullanıcı tarafından yine SYM üzerinde hattın başlangıç ve bitiş noktaları işaretlenerek belirlenir (Şekil 4). Daha sonra, durulan nokta ile silüet hattının başlangıç ve bitiş noktaları arasındaki semt açıları hesaplanarak skyline analizinde kullanılacak olan "From Azimuth" ve "To Azimuth" parametreleri belirlenir.

4. Kullanıcı, durulan noktadan belirlenen silüet hattına göre silüeti üretilecek olan multipatch formatındaki binalar katmanını seçer (Şekil 4). 


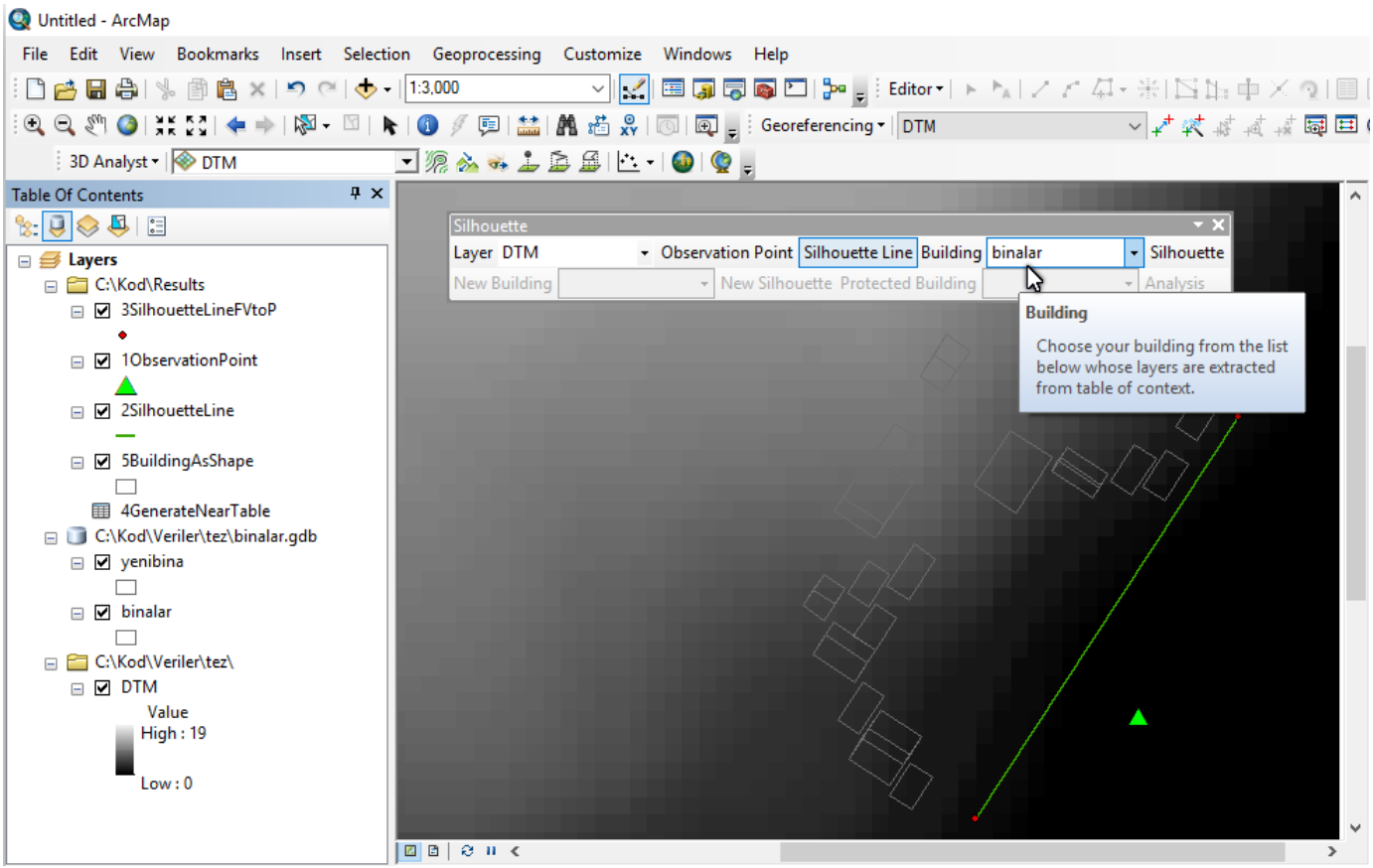

Şekil 4. Yüzey Modelinin Seçtirilmesi, Durulan Noktanın Belirlenmesi, Silüet Hattının Belirlenmesi ve Binalar Katmanının Belirlenmesi

5. Araç çubuğundaki Silhouette butonu kullanılarak mevcut binaların SVG formatındaki silüet görüntüsü üretilerek ekranda gösterilir (Şekil 5).

6. New Building isimli açılır kutu kullanılarak kentsel alana yeni yapılacak olan multipatch formatında bina katmanı seçilir (Şekil 6).

7. NewSilhouette isimli buton kullanılarak yeni yapılacak bina ile mevcut binaların

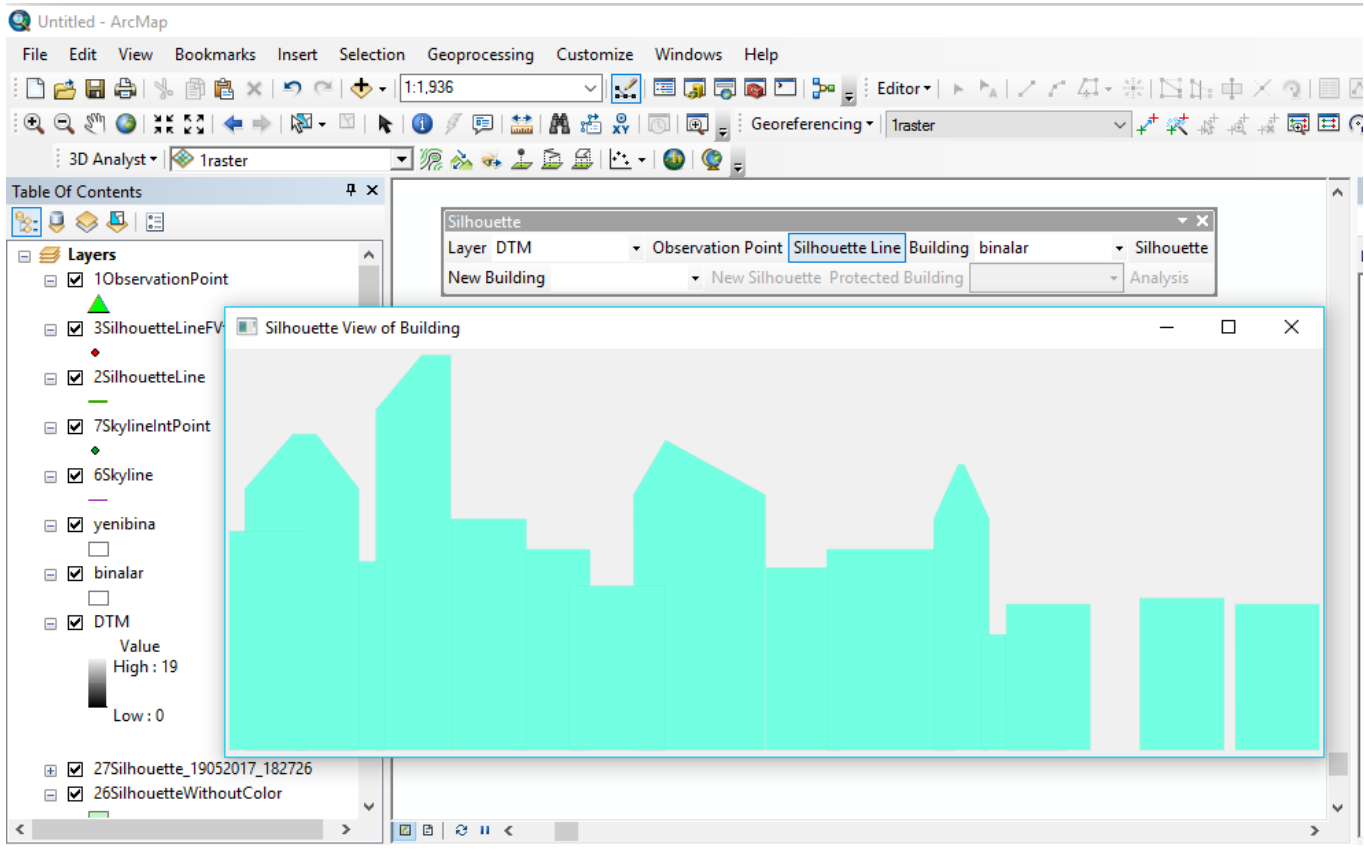

Şekil 5. Silüet Hattına Giren Mevcut Binaların Silüet Görüntüsü 


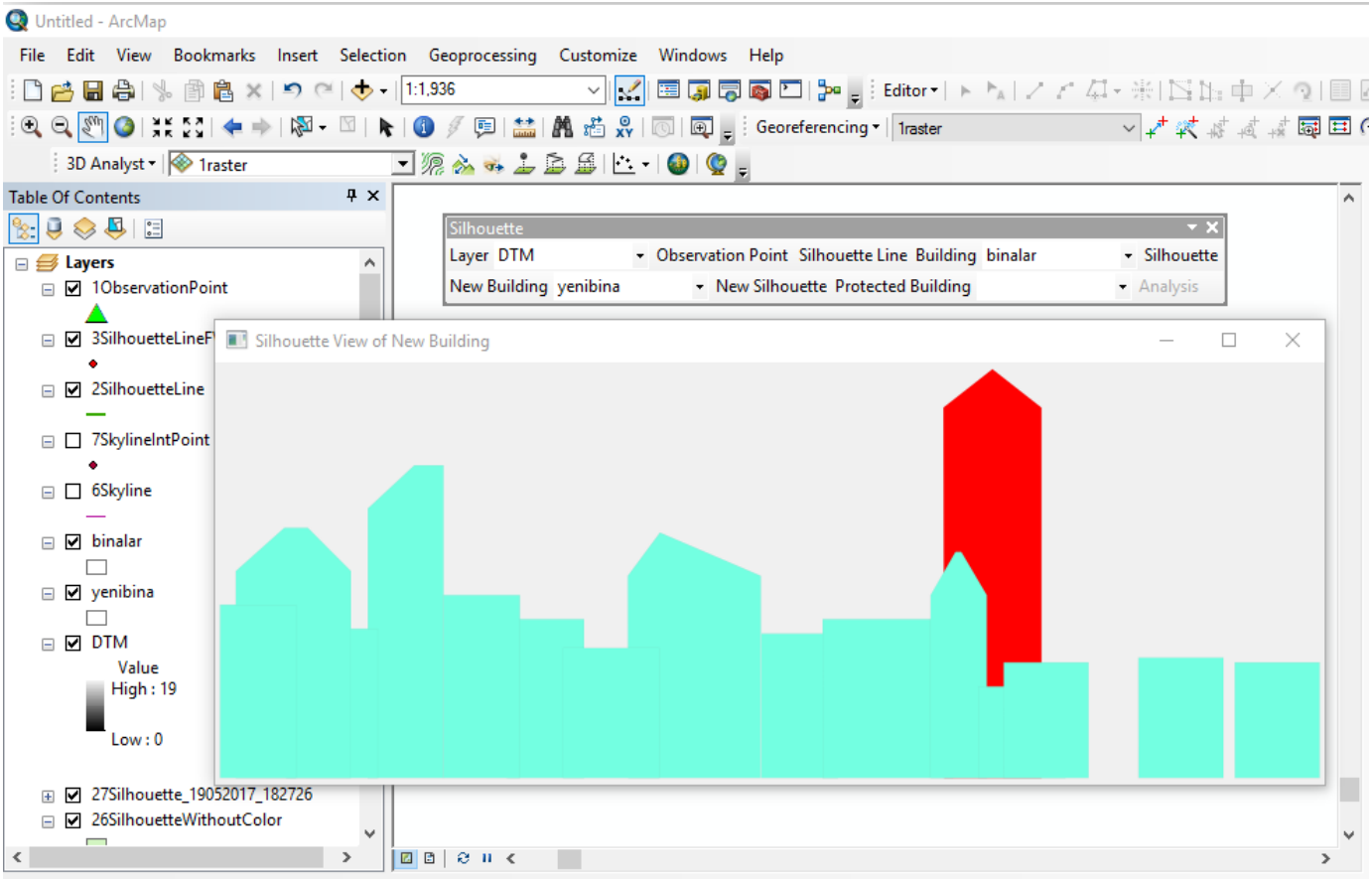

Şekil 6. Yeni Bina Katmanının Seçtirilmesi ile Yeni ve Mevcut Binalara Ait Silüet Görüntüsü

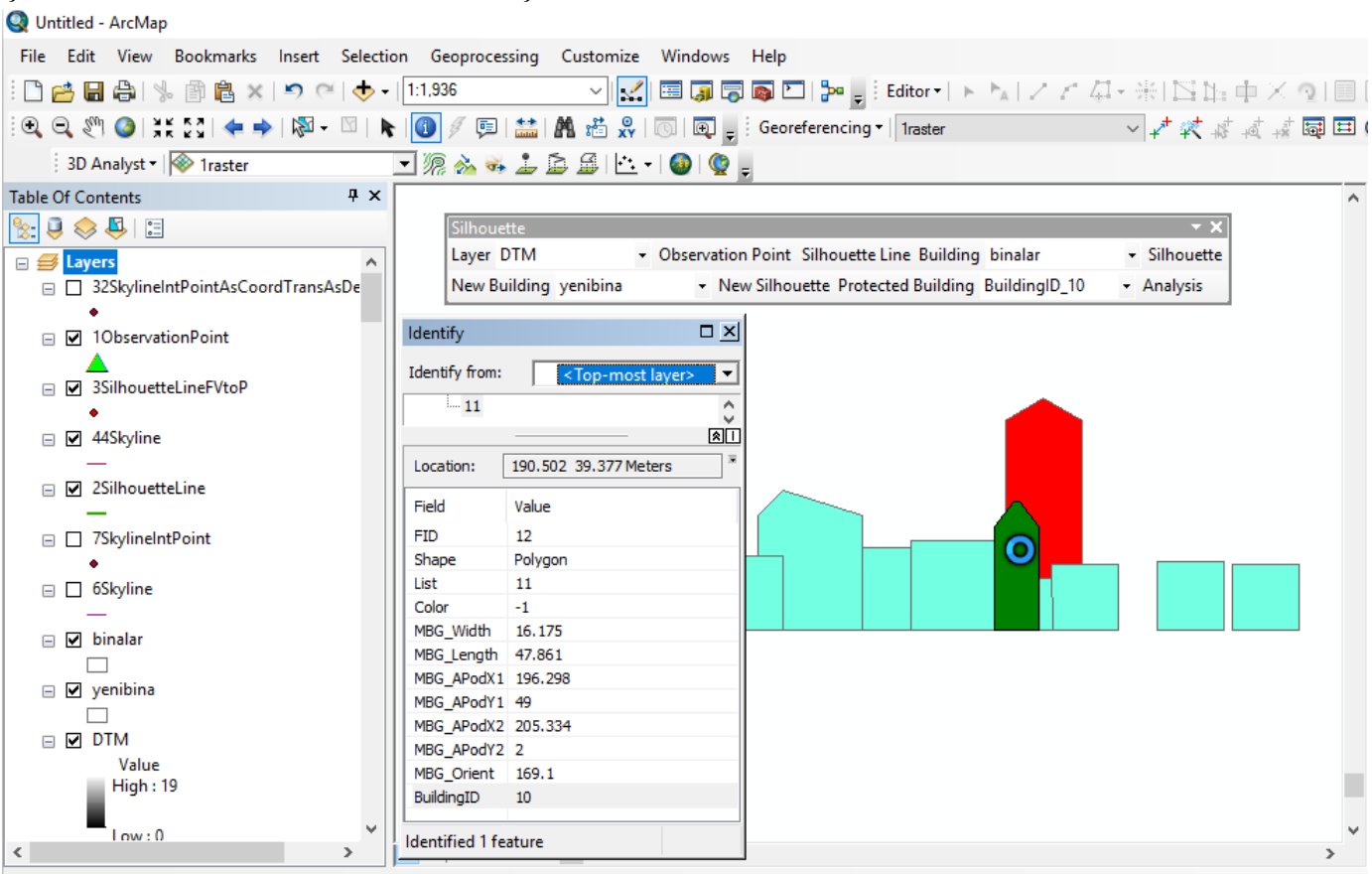

Şekil 7. Silüeti Korunmak İstenen Binanın Seçilmesi

9. Daha sonra, Analysis isimli buton kullanılarak yeni yapılacak bina ile silüeti korunması istenen bina arasında silüet analizi yapılır ve yeni yapılacak olan binanın korunan binanın silüetini bozup bozmadığ değerlendirilir. Silüetin bozulması durumunda, yeni binanın korunan binanın silüetini bozmaması için sahip olması gereken maksimum yüksekliği ve maksimum kat adedi hesaplanır (Şekil 8). Bu işlem, silüeti korunması istenen bina kullanıc1 tarafindan değiştirildiği takdirde yeniden yapılabilmektedir.

10. Yeni binanın korunan binanın silüetini bozmaması durumunda ise ekranda silüetin bozulmadığına dair bir bilgi mesajı görülür (Şekil 9). 


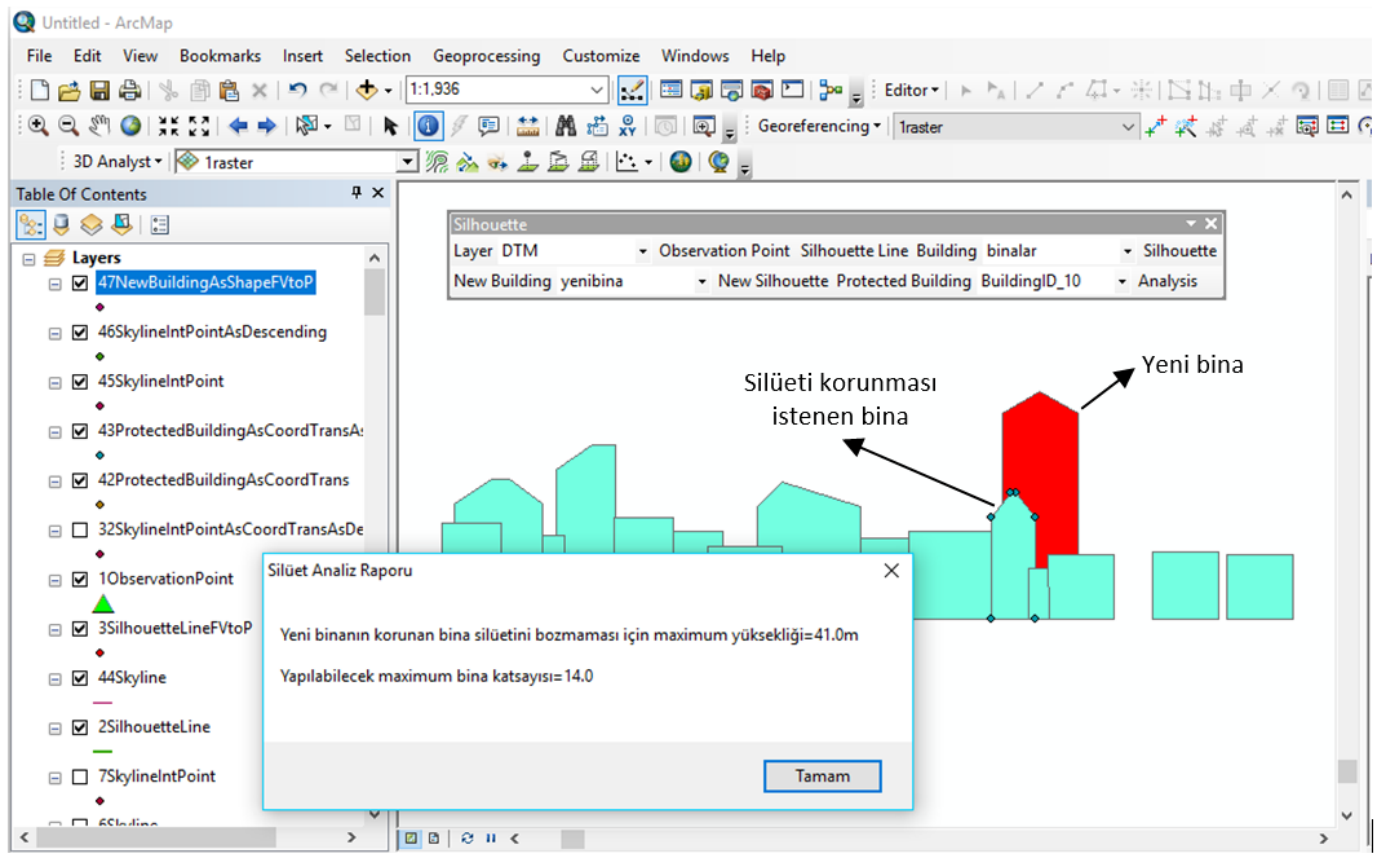

Şekil 8. Silüetin Bozulması Durumundaki Silüet Analizi Sonuçlarının Ekranda Gösterilmesi

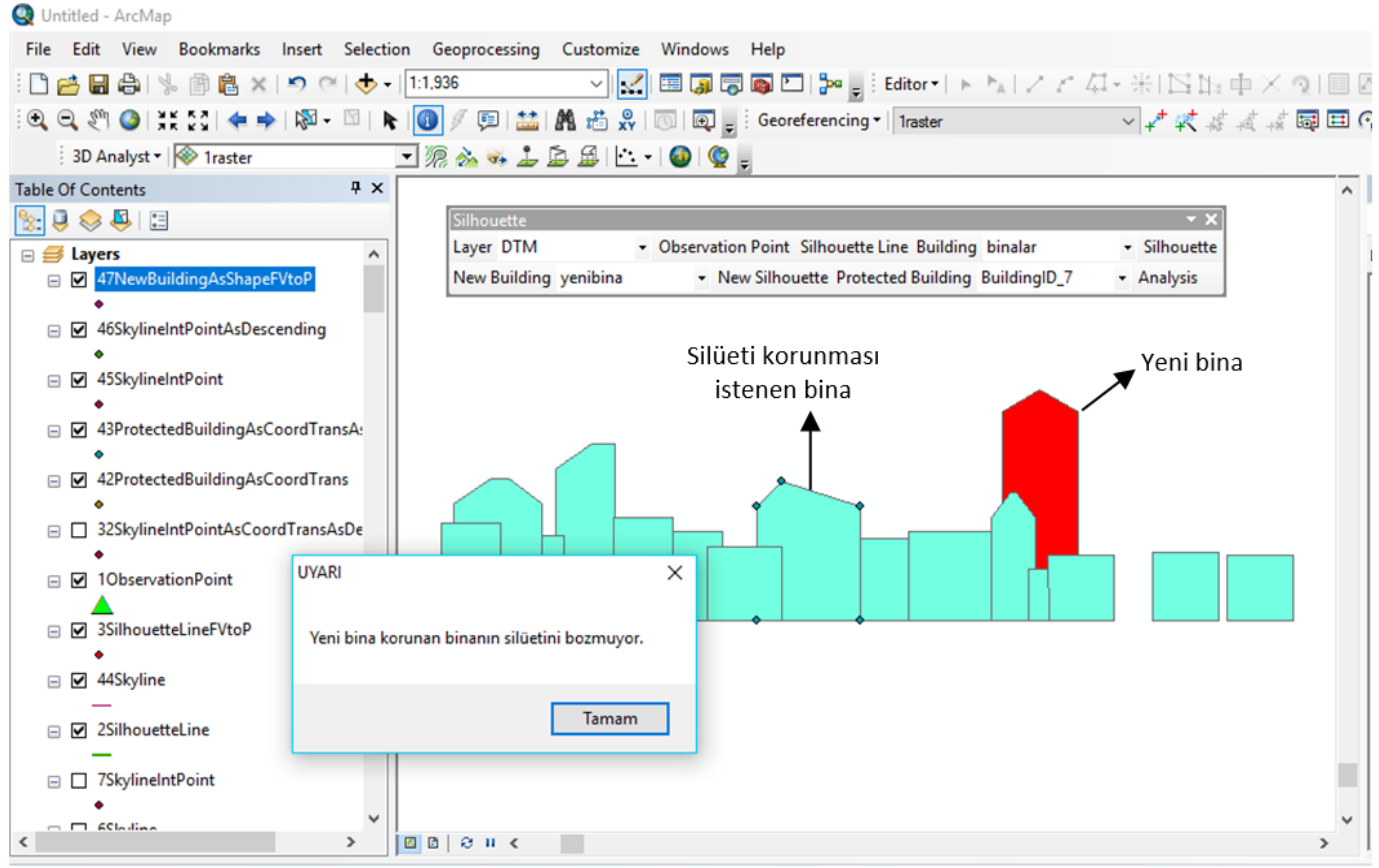

Şekil 9. Silüetin Bozulmaması Durumundaki Silüet Analizi Sonuçlarının Ekranda Gösterilmesi

\section{BULGULAR ve TARTISMA}

Bu çalışmada, gözlem yapılan noktadan belirli bir görüş alanında kalan binaların silüet görüntüsünü üreten ve aynı alanda yapılması düşünülen yeni binaların silüete etkilerini tespit eden yeni bir silüet analiz modülü geliştirilmiştir. Böylelikle kentsel planlama sürecinde ve imar planlarının uygulanmasında karşılaşılan kentsel silüetin bozulmasından kaynaklanan problemlerin çözülmesi amaçlanmıştır.

Silüet analiz modülü, ArcGIS CBS yazılımda çalışacak şekilde Phyton programlama dili kullanılarak geliştirilmiştir. Çalışmada kullanılan 3B binalar, CityGML standartlarına göre LoD 1 detay seviyesinde modellenmiştir. Çünkü LoD seviyesi arttıkça bina modellerinin içerdiği çatı yapıları, bina dokuları, duvar 
detayları ve balkonlar gibi mimari detaylar da artacaktır. Dolayısiyla multipatch geometri tipindeki detay noktaları da artacaktır. Böylelikle multipatch objeyi temsil eden yüzey parçalarındaki nokta koordinatlarının tekrar etmesi hem işlem adımlarında kullanılacak noktayı belirleme aşamasında sorunlar çıkaracak hem de performans açısından geliştirilen modülü yavaşlatacaktır.

Geliştirilen silüet analiz modülünün ArcGIS tarafından sunulan görünürlük analizi fonksiyonlarından ve bu fonksiyonlar kullanılarak literatürde yapılan çalışmalardan farkı aşağıdaki bölümlerde açıklanmıştır.
ArcGIS yazılımına ait görünürlük analizi fonksiyonları kullanılarak, 3B kentsel alanlarda çeşitli görünürlük analizleri yapilabilmektedir. Ancak, sunulan fonksiyonlar ile kentsel alanlardaki silüet durumunun analizi, hem çok sayıda işlem adımı ve parametre gerektirmekte hem de üretilen sonuç görsel olarak yorumlanmaktadır. Gözlem yapilan noktadan 3B kent modeline ait görünür alanlara, Şekil 10'de de gösterildiği gibi skyline analizi ile ulaşılabilmektedir. Görünürlüğün grafiksel olarak yorumlanabilmesi için ise Şekil 10'da verilen skyline grafikleri kullanılmaktadır.
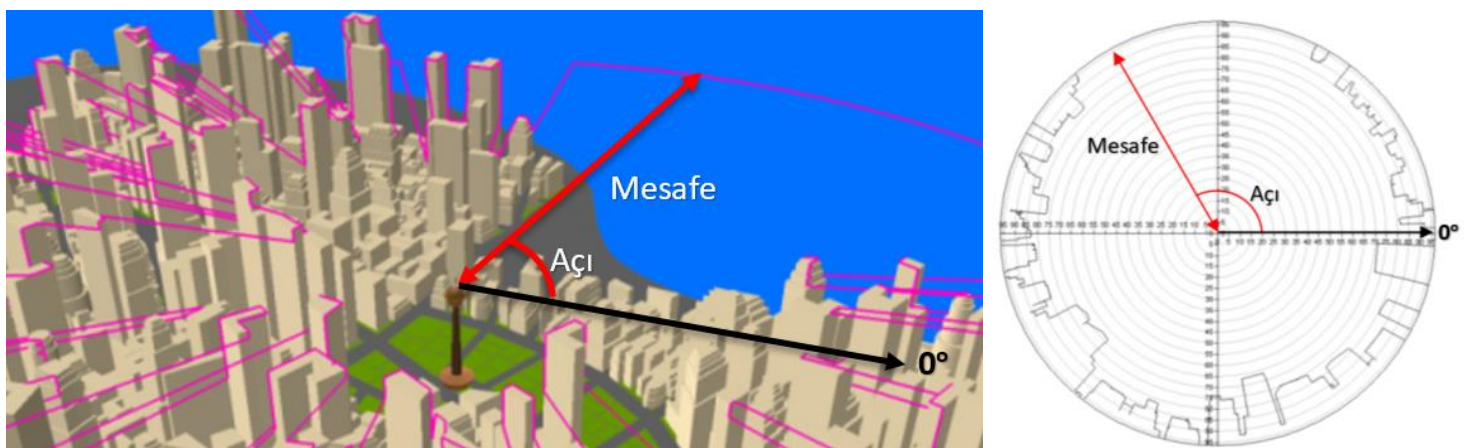

Şekil 10. Skyline Analizi (Solda) ile Skyline Grafiği (Sağda) Üzerinde Açı ve Mesafelerin Gösterimi

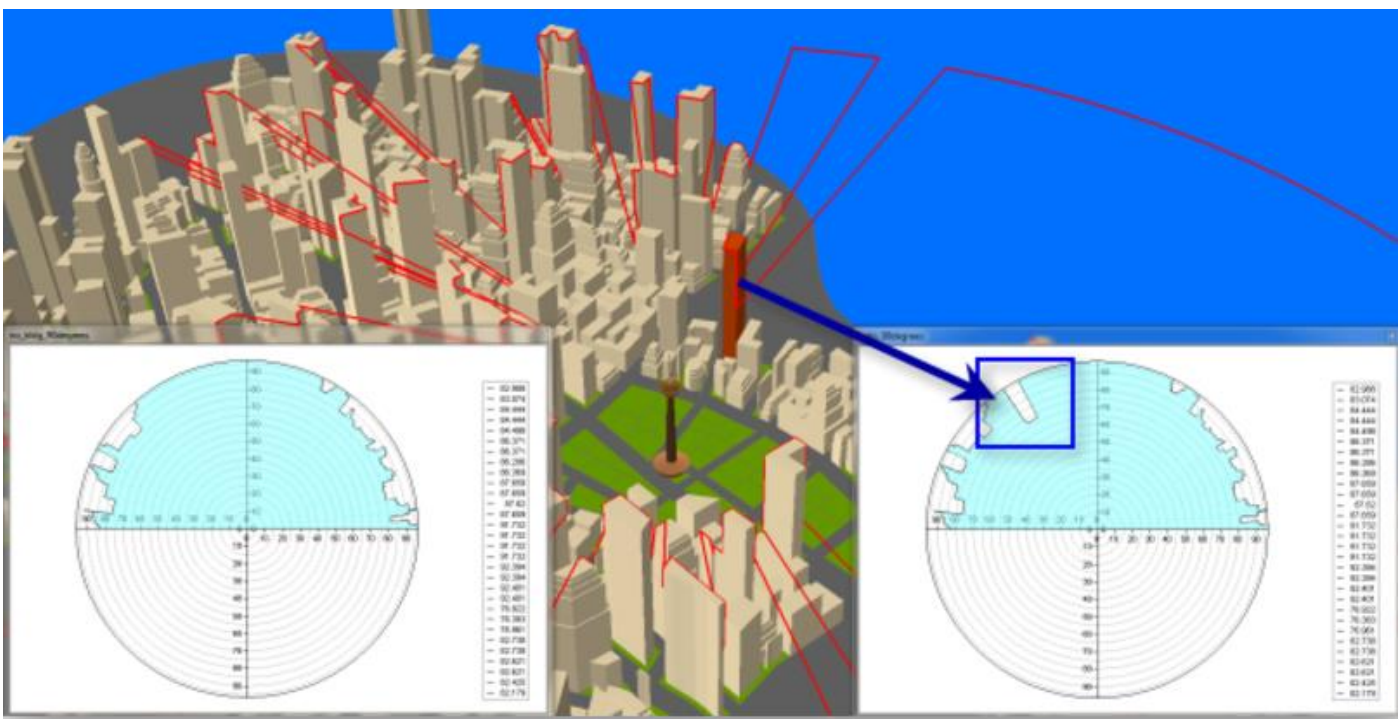

Şekil 11. Skyline Grafikleri Üzerinden Silüet Durumunun Yorumlanması (URL-14, 2016)

ArcGIS yazilımı tarafindan sunulan görünürlük analizi fonksiyonları ile sadece silüete benzer grafik görüntüleri üretilebilmektedir. Grafiklerin görsel olarak yorumlanması ile silüetin bozulup bozulmadığı tespit edilebilmektedir (Şekil 11). Bu grafiklerden gözlem yapılan noktadan görünen binaların yükseklik veya kat adedi gibi bilgilere ulaşılamamaktadır.
Üretilen grafiklerden, sadece gözlem yapılan noktadan ne kadar açı ve mesafede görünür objelerin bulunduğu tespit edilebilmektedir.

Buradan da anlaşılacağı gibi yeni yapılacak binanın, gözlem yapılan noktadan silüeti bozup bozmadiğı görsel olarak belirlenebilmekte ve inşa edilecek yeni bina ile ilgili açı ve mesafe dışında herhangi bir bilgiye ulaşılamamaktadır. 
Ayrıca, silüetinin korunması istenen bina ve yeni bina arasındaki silüet durumu da analiz edilememektedir. Başka bir ifadeyle, yeni yapılacak binanın silüeti bozmaması için inşa edilmesi gereken maksimum yükseklik veya kat adedi ile ilgili bilgilere ulaşılamamaktadır.

Literatürde, ArcGIS yazilımının sunduğu görünürlük analizi fonksiyonları kullanılarak gerçekleştirilen bazı silüet çalışmaları bulunmaktadır. Örneğin; Güney vd. (2012) tarafindan yapılan çalışmada, İstanbul'un Levent semtinin 3B kent modeli üretilmiş ve çalıșma alanına ait hem görsel skyline analizi (visual skyline analysis) hem de zamansal skyline analizi (temporal skyline analysis) olarak belirtilen analizler gerçekleştirilmiştir. Çalışmada, Levent semtinin 1999 ve 2008 yıllarına ait 3B kent modelleri kullanılarak görsel skyline analizi ile silüet değişimi incelenmiştir. Aynı çalışmada, İstanbul'un Boğaziçi Köprüsü, Fatih Sultan Mehmet Köprüsü, Harem ve Çamlıca Tepesi gibi şehrin önemli 4 farklı noktasından, Levent semtinin zamansal skyline analizi üretilmiş ve inşa edilen yüksek yapılı binaların görsel etkileri değerlendirilmiştir.

Yusoff vd. (2014) tarafindan yapılan benzer bir çalışmada ise, ArcGIS yazılımı kullanılarak Kuala Lumpur şehrinin silüetinin korunmasina yönelik çalışmalar gerçekleştirilmiştir. Burada da 3B kent modeli üretiminin tamamlanmasının ardindan ArcGlobe programı kullanılarak 3 farklı gözlem noktasından mevcut binalara ait silüet görüntüleri üretilmiştir. Ardından, yeni yapılacak 3 farklı binanın aynı gözlem noktası ve görüş açısından görüntüleri üretilmiştir. Böylelikle yeni yapılacak olan binaların kentin silüeti üzerindeki etkileri değerlendirilmiştir. Çalışma alanındaki 3 farklı gözlem noktasından (Ampang Tepesi, Malaysia Middle Ring Road 2 doğu sahili geçidi ve Sungai Besi KuzeyGüney Karayolu) gözlem yapılarak, kırmızı renkte görünen 3 farklı yeni binanın Kuala Lumpur silüeti üzerindeki etkileri değerlendirilmiştir.

Yapılan çalışmalar ve kullanılan 3B analiz fonksiyonlarına ait sonuçlar değerlendirildiğinde, ArcGIS ortamında verilerin üretimi, görselleştirilmesi ve analizi işlemlerinin tek bir platformda toplanmış olmamas1 (ArcMap, CityEngine, ArcScene ve ArcGlobe) ve sunulan görünürlük analizlerinin çeşitliliği, yazılımın silüet çalışmalarında kullanılmasını dezavantajlı hale getirmektedir. $\mathrm{Bu}$ nedenle, silüet analizleri bağlamında yapılan çalışmalarla sadece modellerin görsel etkileri değerlendirilebilmiştir. Silüet analizi olarak bahsi geçen skyline analizleri ile sınırlı sayıda konumsal bilgilere ulaşılmaktadır. Bunların dışında her farklı gözlem noktasından farkl1 silüet oluşacağ 1 için gözlem noktası değiştikçe iş yükü artarak analizlerin tekrarı gerekecektir.

\section{SONUÇ VE ÖNERİLER}

Gerek kentsel alanların planlama sürecinde gerekse imar planlarının uygulanmasında yeni inşa edilen binalara ruhsat verilmesi aşamasında, kentsel alanların silüet görüntülerinin üretilmesine ve kent silüetindeki değişimin izlenmesine ihtiyaç duyulmaktadır. Günümüzde kullanılan mevcut CBS yazılımları, silüet analizi için doğrudan fonksiyonlar sunmamakta, fakat sahip oldukları görünürlük analizi fonksiyonları ile silüet benzeri grafiklerin üretilmesine olanak sağlamaktadır. Ayrıca, yeni yapılacak olan binaların, mevcut binalar ile korunması istenen binaların silüetini nasıl etkilediğinin belirlenmesinde ve silüetin korunması için yapılması düşünülen yeni binaların maksimum yüksekliklerinin ve kat adetlerinin belirlenmesinde mevcut CBS yazılımlarının sunduğu fonksiyonlar yetersiz kalmaktadır.

$\mathrm{Bu}$ çalışmada, 3B bina modelleri üzerinde silüet analizi gerçekleştirebilecek bir silüet analiz modülü geliştirilmiştir. Geliştirilen modül, kullanıcının ekrandan belirleyebileceği gözlem yapılan nokta olan bir durulan nokta ve görüş hattındaki 3B binaların silüet görüntüsünü üretmekte ve yeni yapılacak binaların silüeti bozmaması için sahip olması gereken maksimum yüksekliği ve kat adetini hesaplamaktadır. Silüet analizi modülü, özellikle belediyelerin İmar Müdürlüklerinde görevli kullanıcıların, çok fazla teknik bilgiye ihtiyaç duymadan kolaylıkla kullanabilmeleri için basit ve fonksiyonel olarak tasarlanmış ve geliştirilmiştir. Geliştirilen silüet analizi modülü kullanılarak özellikle İstanbul gibi mega kentlerin silüet görüntüleri üretilebilir ve silüetteki zamansal değişim analiz edilebilir. Ayrıca, bu büyük kentlerdeki tarihi dokunun korunması için yeni yapılacak binaların silüete etkisi geliştirilen modül sayesinde tespit edilebilir. $\mathrm{Bu}$ nedenle geliștirilen modülün 
belediyelere önemli katk1 yapacağ1 düşünülmektedir.

\section{KAYNAKÇA}

Akdag, S. G., Cagdas, G., Guney, C. (2010). Analyzing the Changes of Bosphoru Silhouette, in education and research in computer aided architectural design in Europe (eCAADe), September, Zürich. 28th Conference: Future Cities, 815-823.

Ban, Y., Jakobsson, P., Kjelldahl, L., Ranhagen, U. (2011). Visualization in ViSuCity, a tool for sustainable city planning, Proceedings of SIGRAD 2011. Evaluations of Graphics and Visualization - Efficiency, Usefulness, Accessibility, Usability, November 17-18, KTH, Stockholm, Sweden, 105-109.

Czerwinski, A., Sandmann, S., Stöcker-Meier, E., Plümer, L. (2007). Sustainable SDI for EU noise mapping in NRW - best practice for INSPIRE, International Journal of Spatial Dana Infrastructures Research, 2, 90-111.

Czyńska, K. (2015). Impact of Tall Buildings on the Attractiveness of Urban Landscape-On the Example of Selected European Cities, Norway Grants, 131-144.

Güney, C., Girginkaya, S. A., Cağdaş, G., Yavuz, S. (2012). Tailoring a Geomodel for Analyzing an Urban Skyline, Landscape and Urban Planning, 105, 160-173.

Kluijver, H. de., Stoter, J. (2003). Noise mapping and GIS: optimising quality and efficiency of noise effect studies, Computers, Environment and Urban Systems, 27, 1, 85102.

Lamberti, F., Sanna, A., Ramirez, E. (2011). Webbased 3D visualization for intelligent street lighting, In Proceedings of the 16th International Conference on $3 D$ Web Technology (Web3D '11), June 20-22, Paris, France.

Lee, J., Zlatanova, S. (2008). A 3D data model and topological analyses for emergency response in urban areas, International Society for Photogrammetry and Remote Sensing (ISPRS), London, Geospatial information technology for emergency response, 143-168.

Mao, B. (2011). Visualisation and Generalisation of 3D City Models, Doctora Thesis, K. T. H., Stockholm.

Masry, S.E., Lee, Y.C. (1988). An Introduction to Digital Mapping, Department of Surveying Engineering publication, UNB, Canada.

Nasar, J. L., Terzano, K. (2010). The Desirability of Views of City Skylines After Dark, Journal of Environmental Psychology, 30, 215-225.
Sadek, E. S. S. M., Ali. S. J. B. S., Rosdi, B., Kadzim, M. R. B. M. D. (2002). The Design and Development of a Virtual 3D City Model, 1-12.

Schulte, C., Coors, V. (2008). Development of a CityGML ADE for dynamic 3D flood information, In Proceedings Joint ISCRAM-CHINA and GI4DM Conference on Information Systems for Crisis Management, Harbin, China.

Stoter, J. E., Ploeger, H. D. (2003). Registration of 3D objects crossing parcel boundaries, $F I G$ Working week 2003, April, Paris.

Stoter, J., Zlatanova, S. (2003). 3D GIS where are we standing?, International Society for Photogrammetry and Remote Sensing (ISPRS), Joint Workshop on Spatial, Temporal and Multi-Dimensional Data Modelling and Analysis, October, Quebec city, 6.

Şahin, C., Ergun, B., Alkiş, A. (2012). Yakın Resim Fotogrametrisinde Üç Boyutlu Silüet Örnek Uygulaması: İstanbul Galata Bölgesi, $I V$. Uzaktan Algilama ve Coğrafi Bilgi Sistemleri Sempozyumu, Zonguldak.

Tafahomi, R., Hosseini, S. M. S. A., Lamit, H., Burshri, A. (2016). Application of GIS Method to Identify Urban Silhouette Form Case study: Mashhad city in Northeast of Iran, Planning Tech, 1-8.

Tavernor, R., Gassner, G. (2010). Visual Consequences of the Plan: Managing London's Changing Skyline, City, Culture and Society, 1, 99-108.

Van Wees, J.D., Versseput, R.W., H. J. Simmelink, Allard, R. R. L., H. J. M. Pagnier. (2002). Shared Earth system models for the dutch subsurface, Netherlands Institute of Applied Geoscience TNO-National Geological Survey.

Yang, P. P., Putra, S. Y., Li, W. (2007). Viewsphere: a GIS Based 3D Visibility Analysis for Urban Design Evaluation, Environment and Planning B: Planning and Design, 34, 971-992.

Yastıklı, N., Çetin, Z., Arslan, E. (2017). Sayısal Yersel Fotogrametri Yöntemi ile Saryyer İstanbul'da Siluet Üretimi, TUFUAB IX. Teknik Seтроzуити, Afron, Türkiye, 193197.

Yusoff, N. A. H., Noor, A. M., Ghazali, R. (2014). City skyline conservation: sustaining the premier image of Kuala Lumpur, 4th International Conference on Sustainable Future for Human Security, Sustain, 583592.

Zlatanova, S., Painsil, J., Tempfli, K. (1998). 3D object reconstruction from aerial stereo images, Journal of WSCG, 6, 1-3. 